\title{
Ceo Pay-Performance Sensitivity in the SOUTH AFrican CONTEXT
}

\author{
Mark Bussin \\ Department of Industrial Psychology and Human Resource Management, University of \\ Johannesburg \\ Accepted: October 2014
}

\begin{abstract}
The topic of executive pay-performance sensitivity has resulted in mixed research findings. Literature related to executive remuneration constructs, company performance measures and the underlying theories is critically reviewed in this article. The literature is compared to research findings within the South African context pre, during and post the Global Financial Crisis of 2008. The researcher found similar results in the South African context compared to research in other countries and industries. The research challenges the notion that there is one dominant theory driving CEO compensation. The principal-agent theory, supported by the optimal contract theory, are foremost during periods of strong economic performance, while the influence of managerial power and other behavioural theories appear to prevail during periods of weak economic performance. This article proposes some critical considerations in order to manage this tension.
\end{abstract}

Key words: CEO remuneration, compensation, pay-performance sensitivity, principal-agent theory, company performance, optimum contracting, governance, South Africa

JEL: L1, 2, J3, G2, 3

\section{Introduction and literature review}

\subsection{Context}

In 2008 the financial services industry went into a liquidity crisis; Lehman Brothers and Bear Stearns were decimated, while other banks received government bail-outs. Bebchuk, Cohen \& Spamann (2010) indicated that executives in the financial services industry, and in particular at Bear Sterns and Lehman Brothers, were well compensated despite the risks that eventually led to the downfall of both companies and the global recession that ensued. The South African retail sector was also hard hit from the onset of the financial crisis of 2008. Englund and MacDonald (2008) reported that retail sales in September of 2008 declined by 1.2 per cent. It has been widely argued that executive remuneration policies were partly responsible for the dramatic collapse in market capitalisation of the United States (US) banks and subsequent global economic crisis (Haldane, 2011; Fahlenbrach \& Stultz, 2011; Bebchuk \& Spamann, 2010). The structure of executive remuneration at banks where incentives for taking excessive risks are provided, has been an issue of concern for a number of years (Bebchuk \& Spamann, 2010). The role that incentive remuneration played in causing the financial crisis is evident in the significant corporate governance and regulatory changes that have occurred since the economic recession of 2008. Former IMF chief economist, Raghuram Rajan (2005), tabled a controversial paper suggesting that compensation practices in the financial sector were creating significant risks for the global financial system. He stated that executives in the financial sector received substantial incentive pay-outs despite engaging in business practices that eroded company performance, threatened company sustainability and the entire financial system in the long-term. The argument was built on the sentiment that there is a weak pay-performance relationship which had allowed risky business practices to occur. On 28 April 2013 Business Times published an article called 'Bang goes bank boss pay' (Sunday Times, 2013). The article gave an indication of how South African banks have taken to heart threats in the United Kingdom (UK) and the US to impose a cap on bankers' 
salaries, slashing their CEO's packages. The article also indicated however, that some organisations have not shown similar restraint, paying large salary increases despite poor company performance. Based on the differing outcomes regarding CEO's salaries, it is evident that there is a challenge in finding a balance between remuneration that will attract and retain CEOs but not over pay them, especially when company performance is not favourable.

\subsection{Executive remuneration theory}

Executive remuneration is a broad field. This article focuses on CEO remuneration. A number of prominent academics - Tosi and Gomez-Mejia (1994), Yanadori and Milkovich (2002) and Edmans and Gabaix (2009) - narrowed the focus of executive compensation to that of the CEO. The CEO plays a pivotal role in managing company resources, within the context of a continually changing external environment in order to create value for the shareholders. A great number of academic researchers have investigated the relationship between CEO remuneration and company performance while considering principal-agent relationship as the primary basis.

\section{Principal-agent theory}

The principal-agent relationship arises when the individual who owns an organisation is not the same as the individual appointed to manage or control it. The separation of ownership and control leads to two distinct set of actors. 'The principal' is a shareholder in the corporation and 'the agent' acts as a manager for the principal. Agents are often viewed as utility maximisers and if they are not monitored, they place their own interests above those of the principal whom they serve (Hope \& Thomas, 2008). This is counter the shareholders' desire for profit maximisation (O'Reilly \& Main, 2010). The principal-agent conflict is further exacerbated by the fact that the various actors experience differing levels of risk. It is unlikely that the CEO will ever experience the same risk as shareholders without pledging his or her own capital; and shareholders typically employ agents so that they can focus on running the business from a pragmatic perspective, free of the emotional burden that investor risk creates. According to the agency framework, CEO remuneration is an efficient means of aligning executive interests more closely with those of shareholders through a remuneration contract that rewards superior company performance (Jensen \& Meckling, 1976). Corporate governance mechanisms are also utilised to ensure that the interest of both the principal and agent are aligned. According to McKnight and Weir (2009), corporate governance mechanisms are used to "realign the interests of agents and principals and so reduce agency costs".

Much criticism has been levelled at companies and their remuneration committees for the increases in CEO compensation in the face of disappointing financial results. Ozkan (2007) stated that it is widely felt that the link (correlation) between executive remuneration and company performance is not strong enough, meaning that executives receive their remunerations regardless of the results of their respective organisations. The amount of legislation dealing with executive remuneration has thus increased in terms of requiring remuneration contracts that reward superior organisation performance (Morrissey, 2009). The corporate governance and disclosure requirements, that are currently applicable in South Africa through the implementation of the Companies Act (2008) and King Code and Report on Governance in South Africa (King III) (Institute of Directors Southern Africa, 2009), have given a clear indication that there is a need to ensure that executive remuneration is linked to company performance.

\section{Optimal contracting theory}

The need for greater alignment has given rise to an optimal contracting theory which focuses on aligning both managers' and shareholders' interests through the use of financial incentives (Jensen $\&$ Meckling, 1976). The literature suggests that pay-performance sensitivity is dependent on achieving an optimal contract and deviations from an optimal contract result in weak payperformance sensitivity. Edmans and Gabaix (2009) proposed that optimal contracts should "attract talented CEOs and incentivise them to exert effort, exploit growth opportunities and reject 
wasteful projects, while minimising the cost of doing so". Optimal contracting is accepted as a key approach to remedying the fundamental agency problem afflicting management decision-making. Advocates of the optimal contract theory seek to achieve greater pay-performance sensitivity.

Managerial power theory

There are also alternate theories that have been proposed regarding the drivers of executive compensation. Gabaix and Landier (2008) proposed labour market considerations and the lack of suitably-skilled CEOs as undermining factors in the determination of CEO compensation. The dominant response to the optimal contracting theory has been that of the managerial power theory. Managerial power theory suggests that rather than serving the shareholders' interests, boards are 'captured' by the CEO and made to serve his or her interests (O'Reilly \& Main, 2010). Cheng and Indjejikian (2009) supported the managerial power issue, indicating that CEOs have strong negotiation power with their boards. Similarly, Bebchuk and Fried (2004) provided a compelling argument for behavioural considerations indicating that managerial power plays a perverse role in the determination of CEO compensation. Managerial power is thus both a potential instrument for addressing the principal-agent theory and a part of the problem itself (Bebchuk \& Fried, 2003). It is suggested that CEOs have influenced remuneration committees to increase fixed-pay (despite poor company performance) in order to compensate for the loss of short- and long-term incentive pay-outs (Frydman \& Jenter, 2010). Through managerial power, CEOs are able to influence boards and compensation committees and thus influence the structure of their remuneration packages (Doscher \& Friedl, 2011).

The extent to which an organisation can develop a remuneration structure that links remuneration outcomes to measures of company performance, remains a key management challenge. Remuneration structures and -policies have been subject to challenges in the form of behaviourist complications. Research done into the factors driving changes in remuneration policies in South Africa, showed that financial results of the company, governance and merit pay are key factors that are receiving closer attention; reflecting a greater shareholder expectation that pay should be linked to performance (Bussin \& Huysamen, 2003; Bussin \& Satram, 2012).

\subsection{Remuneration constructs}

A remuneration package has various levels: salary; annual bonus and long- and short- term performance incentives (Frydman \& Jenter, 2010). The financial reward system can be segmented as follows $\left(21^{\text {st }}\right.$ Century Pay Solutions Group, 2010):

Figure 1

Total reward

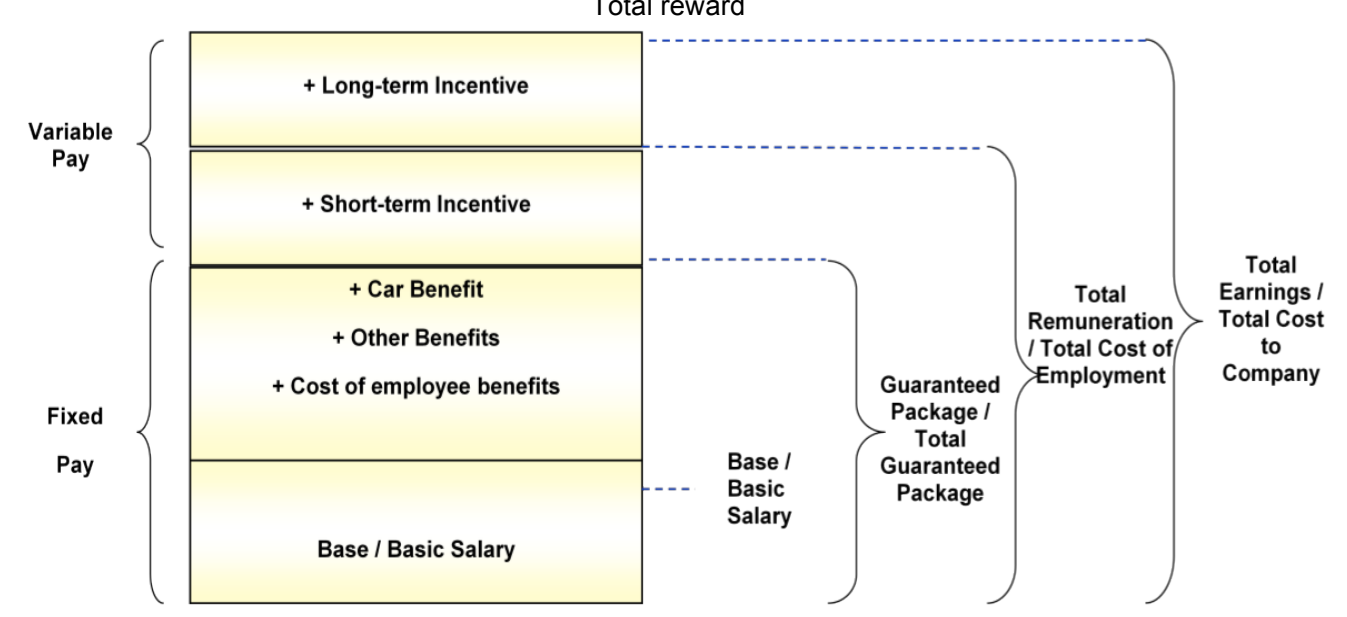

Source: 21st Century Pay Solutions Group (2010) 
Well-designed incentives or variable packages should be linked to the financial performance of the company, however the issue of guaranteed cost to company (CTC) pay solutions for CEOs, warrants further investigation (Hoi \& Robin, 2004).

The remuneration concept has various constructs (Ellig, 2007):

- 'Salary': guaranteed pay that the executive will receive which is normally a risk-free monthly payment.

- 'Benefits and perquisites': constructs such as health care, survivor protection and retirement funds.

- 'Short-term incentives': cash payments for achieving of short-term and standard annual goals and objectives.

- 'Long-term incentives': multi-yearly and could include equity-based payments.

Further definitions (21st Century Pay Solutions, 2010):

- 'Fixed-pay': salary and benefits, all guaranteed components of the remuneration package.

- 'Total remuneration' or 'total cost of employment': fixed-pay and short-term incentives.

- 'Total earnings' or 'total cost to company' (CTC): fixed-pay and all incentives.

Compensation models developed by consultants including WorldatWork (2011), Mercer, Towers Perrin, and academics like Armstrong and Brown (2006) indicate that the main components of CEO compensation include fixed pay, short-term incentives and long-term incentives. The most common determinants for executive pay are organisation size; organisation performance; executive-specific factors; organisation structure; job or position-specific factors and job complexity (Bussin, 2011). Ellig (2007) argues that the structure of an executive's remuneration package will follow the path where it is the easiest for the executive to earn. Should short-term incentives be difficult to obtain due to factors outside the control of the CEO, the structure of the remuneration would lean towards a guaranteed CTC or fixed-pay. The inverse is also true, that should short-term incentives be easier to obtain the structure of remuneration will gravitate towards higher incentive pay. The global trend is to cut or suspend short-term, long-term and incentive bonuses. The South African trend for upper- and middle-management mirrors this showing the trimming of benefits and bonuses (Bussin, Makhubela \& Quail, 2009). This highlights the need to better understand the guaranteed CTC of CEOs and how this is aligned to the determinants of executive remuneration structure.

\subsection{Company performance measures}

According to Frydman and Jenter (2010), a remuneration package of an executive has various levels which consists of basic salary, annual bonus, short-term and long-term performance incentives. Similarly, organisation performance can be operationalized in many different ways, accounting-based measures and market-based measures (Attaway, 2000). Fatemi, Desai \& Katz (2003) argue that such measures do not account for the risk incurred by the organisation's executive in their search for growth and profitability; suggesting two additional measures, namely economic value added (EVA) and market value added (MVA). According to the economic theories of remuneration, company performance should affect an executive's remuneration only to the extent that it serves as a proxy for unobservable managerial effort or productivity. Although these theories uniformly suggest a relationship between compensation and observed performance, most analyses are not in agreement with regard to the measure of company performance. In the empirical compensation literature there is no consensus on the optimal measure of company performance as researchers have operationalised organisation performance in many different ways (Bacidore, Boquist, Milbourn, Thakor, 1997; Attaway, 2000; Eriksson \& Lausten, 2000; Carpenter \& Sanders, 2002; Fatemi et al., 2003). Therefore, measures of company performance can be divided into three main categories: absolute financial performance measures (audited measures within a specific year), financial performance ratios (ratios derived from absolute performance measures) and market performance measures (performance within equity markets). 
General observations with regard to previous studies by researchers on the pay-for-performance link used different company performance measures and usually highlight the advantages in their chosen company performance measures and disadvantage in the company performance measures not chosen. For example, the study by Murphy (1985) argues that company performance should be measured by market-based measures because they reflect shareholders' wealth while pointing out few weaknesses in considering accounting-based measures, e.g. accounting-based measures are considered to be either backward looking or there is danger of these measures being manipulated by executives to make themselves look good.

In terms of accounting-based company performance measures, the following are some of the practices executives commonly use to manipulate indicators: manipulating depreciation policy (accelerated versus straight-lie); changing inventory valuation procedures; using short-term, noncapitalised leases to obtain productive equipment; and using window dressing techniques such as holding borrowed money as cash until the end of an organisation's financial year to make sure that the organisation's balance sheet looks favourable. The Health \& Racquet, Enron and WorldCom scandals are some of the few examples in manipulating accounting-based measures.

To the contrary, Carpenter and Sanders (2002) contend that accounting-based measures are more informative of the managerial contribution than market-based measures because they are less affected by the noise of the market. Research studies in support of accounting-based measures include those done by Madura, Martin \& Jessell (1996) which points out that there are shortcomings with stock prices as a measure of company performance because stock prices tend to move with the market, which can hide the difference in cross sectional performance over a given period.

Since company shareholders are generally considered to be the principals in agency theories, it may seem appropriate to define company performance in terms of market-based measures rather than accounting-based measures. In this proposal the market will provide a source of information for shareholders that is 'independent' of the company and its agents. Additionally, as accounting standards around the world are continually being tightened it is suggested that the opportunity to manipulate accounting-based measures will continue to be reduced over time. As a result, researchers like Eriksson and Lausten (2000) conclude that they do not see the use of accountingbased measures in the form of accounting profits as a company performance measure, as any great disadvantage to their analysis. Company market-based performance measures include stockholders equity, stock performance (return on common stock and changes in market value). Accountingbased measures include profitability (earnings per share, return on investment, and total profits).

The market- and accounting-based company performance measure examples illustrate that by their very different nature, the weak association between these two types of measures is not unexpected. A 2010 study by Gentry and Shen (2010) investigated the relationship between accounting and market measures of company performance. Using financial data from all publicly traded firms in the COMPUSTAT from 1961 to 2008 they found that although measures of accounting profitability and market performance correlate positively across industries, their covariance is less than 10 per cent and provides no evidence of convergence. Both company performance measures are valid estimators but from different perspectives; accounting-based measures capture historical performance while market-based measures capture future performance.

In addition, in order to avoid potential biases inherent in using either market-based or accounting-based company performance measures, researchers like Canarella and Gasparyan (2008) suggest using both accounting- and market-based measures in establishing the closest link between the CEO remuneration and company financial performance.

Other research studies have indicated that measures based on accounting or the market may bear little resemblance to the economic return earned by the organisation since, for example, accounting-based measures, do not account for the risk incurred by the organisation's executives in their search for growth and profitability (Bacidore et al., 1997; Kyriazis and Anastassis, 2007; Fatemi et al., 2003). As a result, these research studies have suggested two additional measures into investigating the relationship between executive remuneration and risk-adjusted organisation performance measures, namely economic value added (EVA) and market value added (MVA). 
Economic value added (EVA) measure was devised by Stern Stewart \& Co. a worldwide management consulting firm founded in New York in 1982 (Stewart, 1990). Economic value added is a performance measure that attempts to measure and capture the true economic profit of an organisation by providing a measurement of an organisation's economic success (or failure) over a period of time (Ward \& Price, 2006). Market value added (MVA), on the other hand, is simply the difference between the current total market value of an organisation and the capital contributed by shareholders. Market value added (MVA) is not a performance metric like economic value added (EVA), but a wealth metric instead, which measures the level of value an organisation has accumulated over time.

Chari (2009) did a comprehensive literature review on different performance measures used by organisations, focusing on a comparison between EVA and other performance measures. The research study by Chari (2009) verified the soundness of claims made by proponents of EVA, that EVA was superior to other metrics as it is the financial performance measure that comes closer than any other measure in capturing the true economic profit of an organisation which helps executives make better decisions and motivates them to perform better. According to Stewart (1990), "EVA stands well out from the crowd as the single best measure of wealth creation on a contemporaneous basis and is almost 50 per cent better than its closest accounting-based competitor (including earnings-per-share (EPS), return-on-equity (ROE) and return-on-Investment (ROI) in explaining changes in shareholder wealth" (Chari, 2009).

\subsection{Pay-performance sensitivity}

Murphy (1985) found that fixed pay, short-term incentives and total earnings are positively related to total shareholder return and measures of company performance. Pay-performance sensitivity refers to the correlation between remuneration outcomes and measures of company performance, with not one definitive measure but rather a broad set of variables.

The literature on pay-performance sensitivity has yielded mixed results. Gerhart and Milkovich (1990) found that variable pay is positively correlated with company performance but that fixed pay is not sensitive to company performance. Jensen and Murphy (1990) concluded that for every $\$ 1000$ change in market value, the CEO would experience a $\$ 2.59$ change in total remuneration. Concluding that while the pay-performance relationship was positively correlated, it was not particularly favourable and was declining over time. Belliveau, O'Reilly III \& Wade (1996) showed evidence of a positive relationship between CEO pay and company performance. Abowd (1990) analysed the pay-performance relationship and found that greater use of variable pay was positively related to total shareholder return and gross economic profit. Other studies include those done by Coughlan and Schmidt (1985) which studied the relationship between CEO remuneration and stock price performance and their results led them to conclude that the two were linked. Veliyath and Bishop (1995) also found a strong relationship between executive remuneration and stockholders equity.

US industry specific studies include those done by Akhigbe, Madura \& Ryan (1997) in commercial banks, and Barber, Ghiselli \& Deale (2006) in the restaurant segment of the hospitality industry. The Akhigbe et al. (1997) study found that the accumulated human capital of CEOs and the commercial bank size were positively related to the total CEO remuneration which included salary, bonus, and stock options. The study also found that CEO remuneration had a positive significant relationship with both accounting-based performance measures and marketbased performance measures. Barber et al. (2006) found a positive link (correlation) between executive remuneration and share price for larger restaurant organisations. A study by Merhebi, Pattenden, Swan \& Zhou (2006) examined 722 Australian organisations between 1990 and 1999 and found results which were consistent with other findings for organisations in the US, UK and Canada when market-based model specifications were used. Their results found that CEO remuneration and company performance association is positive and statistically significant. Firth, Fung \& Rui (2006) conducted a CEO pay-performance study in China. Their study found that there was a positive relationship between CEO remuneration and company performance measured 
in both accounting and shareholder wealth terms.

Research conducted in the UK where Stathopoulus, Espenlaub and Walker (2005) found that there was a link between higher-performing companies and executive remuneration, and that the link between poorer-performing companies and executive remuneration was weak.

In contrast, numerous studies have found little evidence of a positive relationship between the two variables (Tosi, Werner, Katz \& Gomez-Mejia, 2000). Jensen and Murphy (1999) studied large organisations in the US, testing the relationship between CEO wealth and shareholder wealth and found little evidence of a relationship between executive remuneration and company performance. Duffhues and Kabir's (2008) research supports these results finding no evidence of a positive relationship between executive remuneration and company performance. Gregg, Jewell and Tonks (2005) also found the link between executive remuneration and company performance to be weak.

Varying methods of data collection, statistical techniques, samples and industry contexts may contribute to these variances. Empirical compensation literature indicates that there is no consensus on the optimal measure of company performance as researchers continue to operationalise company performance in many different ways (Bacidore et al., 1997; Attaway, 2000; Fatemi et al., 2003; Chari, 2009). Finally, the literature suggests that moderator variables may play a role in the pay-performance relationship, such as the size of the firm and the role of monitoring systems within the organisation. Firm size is shown to have a large influence on the variance of CEO pay-performance sensitivity (Tosi et al., 2000; Haynes, Thompson \& Wright, 2007), while the impact of monitoring remains unclear in the face of conflicting evidence (Petra \& Dorata, 2008; Lee, Lev \& Yeo, 2007).

\section{The South African context}

With the wealth of pay-performance sensitivity research in different geographies and industries showing mixed results, this article aims to examine four studies conducted in the South African context in different industries in order to understand the pay-performance relationship in the South African context.

The growing role of governance within the South African context must be acknowledged. A pursuit of more effective governance structures has resulted in many countries adopting a code of corporate governance (Collier, Idensohn \& Adkins, 2010). In South Africa, the code driving governance of executive remuneration is known as the King Code of Governance for South Africa. A critical element of King III is the requirement that CEO remuneration be linked to measures of company performance. This has manifested itself in practice guidelines for all of the components of CEO remuneration, including fixed pay, short-term- and long-term incentives. King III does not constitute formal regulation - it is a code of practice as opposed to statutory legislation where legal sanctions are applied for non-compliance. Despite the fact that King III relies only on selfregulation, it appears to have a significant impact on the manner in which CEO remuneration is addressed. King III requires disclosure between salary and performance-related elements as well as an explanation of the basis on which remuneration is measured. This means that it will become increasingly difficult for executive directors not to be remunerated according to performance. In addition, the fact that King III also suggests that shareholders approve the remuneration policy of a company will increase the accountability of executive directors to shareholders (Scholtz \& Smit, 2012).

In contrast to the deep crisis that occurred in developed nations, the South African banking sector remained reasonably stable. The International Monetary Fund (2009) suggested that despite the crisis intensifying across the world, South African banks had remained 'orderly and stable'. Recently, in the South African mining industry a strike resulted in the tragic death of mine workers as violence broke between the South African Police Services and the mine workers. The strike was owing to the fact that miners were complaining that mining benefits were not reaching the workers and the surrounding communities. More importantly criticism was put on high executive 
remunerations compared to the low wages of the mine workers (Leon, 2012). Although poor company performance was the reason given for low wages, executive remuneration did not reflect a strong pay-performance sensitivity.

\subsection{Pay-performance sensitivity in the South African context}

The following studies were all quantitative, archival studies conducted using South African companies and CEO remuneration data to research the relationship between CEO pay and company performance.

Shaw (2011) looked at financial service companies between 2005 and 2010. His research study categorised company performance measures into three main categories: absolute financial performance measures, financial performance ratios, and market performance measures. Company performance measures were further broken down into: economic profit, accounting profit, and shareholder returns in the form of return on equity (ROE) and headline earnings per share (HEPS). He included two critical company characteristics which are indicators of company performance, namely debt to assets ratio and total assets or book value. His research found a moderate to strong relationship between CEO remuneration and company performance. However, the results of the study indicated that there has been a decline in the relationship since 2008 (the start of the financial crisis). The results of the study also yielded an associated structural change in the mix of remuneration components, "most notably there was an observed shift in CEO remuneration from variable pay to fixed pay" (Shaw, 2011).

Van Blerck (2012) also researched companies in the South African financial sector over 20022011. He used the following company performance measures: economic value added (EVA), return on equity (ROE) and share price. His research supported Shaw's (2011) research findings. Van Blerck (2012) found a moderate correlation between share price and executive remuneration. Additionally, his research found that executive remuneration correlated strongly to EVA, and the correlation strengthened after the 2008 financial crisis.

Nel (2012) looked at the relationship between company financial performance and CEO guaranteed CTC in the South African retail and consumer goods sector. His study reviewed data over a six year period and included the financial crisis (2006-2011). He utilised the DuPont Model to analyse the relationship between CEO remuneration and company financial performance. The DuPont Model includes the performance of management and strategic decisions into the assessment of the financial performance of an organisation. DuPont analysis is an expression which breaks return on equity (ROE) into three parts, namely profitability (measured by profit margin), operating efficiency (measured by asset turnover) and financial leverage (measured by multiplier) (Ward \& Price, 2006). His study illustrated that the financial company performance in the South African retail and consumer goods sector had little or no effect on the CEOs Guaranteed CTC. Nel (2012) suggested that the CEOs' managerial power could have led to an increase in their guaranteed CTC that was misaligned with the financial performance of their respective organisations after the 2008 Global Financial Crisis.

The last study was conducted over a seven year period (2006-2012) using South African companies and CEO remuneration data from various industries (Modau, 2013). Modau studied 21 of the Johannesburg Stock Exchange's (JSE) Top 40 organisations which had a combined market capitalisation of between 50 per cent and 82 per cent of the total JSE Market Capitalisation. Her research used the following company performance measures: market capitalisation (MC), earnings per share (EPS), return on equity (ROE), economic value added (EVA) and market value added (MVA). Modau's (2013) major findings indicate that there was a structural change in the CEOs' total remuneration packages after the 2008 financial crisis. CEOs remuneration structure moved away from short-term Incentives and focused more on fixed pay. This structural change supported Shaw's (2011) research findings. Modau's (2013) findings regarding the positive relationship between CEO total remuneration and ROE support those found by Nel (2012) and Van Blerck (2012). The next most significant finding was that of the relationship between CEO total remuneration and EVA which tended to change direction depending on the global economic 
standing. When the global economy was experiencing uncertainty or difficulty (e.g. 2008 Global Financial Crisis and August 2011 Stock Market Fall), EVA was found to be leaning towards being more directly related to CEO total remuneration. When the global economy was performing well, EVA was found to be leaning towards being more inversely related to CEO total remuneration.

\section{Conclusion}

In theory, efficient compensation contracts should be designed well enough to link CEO remuneration with company performance, providing strong incentives for executives to operate organisations in the best interests of the shareholders. Additionally, one of the aims of the implementation of the Companies Act (2008) and King III was to influence and strengthen the link between executive remuneration and company performance. However, current research discussions highlighted that executives are becoming more innovative in bypassing the payperformance requirement. One such method took precedence after the 2008 Global Financial Crisis as after the event executives have noticeably been moving away from focusing on shortterm incentives and paying greater focus to fixed pay. The primary aim of such a move was mainly to avoid performance related elements in determining their remunerations. This has created a natural disconnect between what executives are being paid and company performance resulting in inverse relationships between some of company performance measures with CEO total remuneration, especially fixed pay. The link between CEO remuneration and company performance has been lost. This is supported by the research in both the South African context, different industries and other geographies.

The relationship between the principal-agent and the managerial power theory is exposed as a fluid relationship, largely dependent on the external environment. The changes observed within the South African context with regards to the weakening relationship between company performance and CEO pay, along with the structural changes in CEO pay and the increased risk profile, suggests that managerial power has become more prominent in light of the deteriorating economic conditions. CEOs have asserted managerial power as suggested by Bebchuk and Fried (2004) and have begun to manage the risk component in their compensation packages. This contrasts with the initial expectation that the level of pay-performance sensitivity would strengthen over the period, based primarily on the influence of increased monitoring and regulation. Instead, the role of the external environment played a far more influential role. As such, pay-performance sensitivity was higher over periods of good performance and lower over periods of weaker company performance. The findings suggest that pay-performance sensitivity is likely to fluctuate based on macroeconomic trends. The research challenges the notion that there is one dominant theory driving CEO compensation. Within the context of the literature the rational principal-agent theory, supported by the optimal contract theory, is found to be strong during periods of strong economic performance, while the influence of managerial power and other behavioural theories appear to be stronger during periods of weak economic performance.

In managing the tension between the principal-agent theory and the managerial power theory, I would propose a number of possible considerations. Firstly, a stronger test of the pay-performance relationship and the power of incentive design is required in order to ensure that executives are rewarded or penalised for poor performance. The question on how executives are paid also needs to be considered. There is also a need for a robust and valid model which contains partial regression coefficients which are positive and significant to ensure consistency with the agency notion that top executives are rewarded for increases in shareholder wealth. Additionally, boards and remuneration committees need to pay more attention to the different accounting- and marketbased measures available, in assessing top executives' performance. Compensation committees are likely to have to make greater use of discretion during periods of poor economic performance as behavioural considerations become more influential. As a result, compensation decision-making policies and processes will need to be robust in order to ensure consistency and fairness in the application of discretion. More attention is also required with regards to the different behaviours 
by top executives in making the Companies Act (2008) and King III requirements ineffective as they avoid being measured for performance. King III needs to be considered while designing better and more robust pay-performance models. Managerial power manifests itself in the need to attract, motivate and retain leadership skills, particularly during periods of economic downturn. A target range of pay-performance sensitivity should be pursued by organisations, rather than an absolute level. This will allow organisations to manage the relationship between the principalagent theory and the managerial power theory within a reasonable level, and with some degree of flexibility. Finally, in managing the impact of managerial power, compensation committees will need to understand the role that size and book value (BV) plays in determining compensation outcomes. It is recommended that compensation committees isolate book value in the measurement of company performance to ensure a more accurate understanding of company performance.

\section{References}

21ST CENTURY PAY SOLUTIONS. 2010. Global reward trends. Johannesburg.

ABOWD, J. 1990. Does performance-based managerial compensation affect corporate performance? Industrial and Labor Relations Review, 43(3):525-735.

AKHIGBE, A., MADURA, J. \& RYAN, H. 1997. CEO compensation and performance of commercial banks. Managerial Finance, 23(11):40-55.

ARMSTRONG, M. \& BROWN, D. 2006. Strategic reward: making it happen. London: Kogan Page.

ATTAWAY, M.C. 2000. A study of the relationship between company performance and CEO compensation. American Business Review, 18(1):77-85.

BACIDORE, J.M., BOQUIST, J.A., MILBOURN, T.T. \& THAKOR, A.V. 1997. The search for the best financial performance measure. Financial Analysts Journal, May/June:11-20.

BARBER, N., GHISELLI, R. \& DEALE, C. 2006. Assessing the relationship of CEO compensation and company financial performance in the restaurant segment of the hospitality industry. Journal of Foodservice Business Research, 9(4):65-82.

BEBCHUK, L.A. \& FRIED, J. 2003. Executive compensation as an agency problem. Journal of Economic Perspectives, 17(3):71-92.

BEBCHUK, L. \& FRIED, J.M. 2004. Pay without performance: The unfilfilled promise of executive compensatio. Cambridge: Harvard University Press.

BEBCHUK, L.A. \& SPAMANN, H. 2010. Regulating banker's pay. Georgetown Law Journal, 98:247-287. BEBCHUK, L.A., COHEN, A. \& SPAMANN, H. 2010. The wages of failure: executive compensation at Bear Sterns and Lehman Brothers 2000 - 2008. Yale Journal on Regulation, 27(2):257-282.

BELLIVEAU, M.A., O'REILLY III, C.A. \& WADE, J.B. 1996. Social capital at the top: Effects of social similarity and status on CEO compensation. Academy of Management Journal, 39(6):1568-1593.

BUSSIN, M. \& HUYSAMEN, D. 2003. The factors driving change to remuneration policy and outcomes. South African Journal of Human Resource Management/SA Tydskrif vir Menslikehulpbronbestuur, 2(2): 45-54

BUSSIN, M., MAKHUBELA, K. \& QUAIL, N. 2009. The impact of recession on global pay, February 06, 2012. Available at: www.21century.co.za [accessed 2014-01-02].

BUSSIN, M. 2011. The remuneration handbook for Africa, Johannesburg: Knowledge Resources.

BUSSIN, M. \& SATRAM, L. 2012. Factors driving changes to remuneration policies in South Africa. Working Paper, Department of Human Resource Management, University of Johannesburg.

CANARELLA, G. \& GASPARYAN, A. 2008. New insights into executive compensation and firm performance: Evidence from a panel of 'New Economy' firms, 1996-2002, Managerial Finance, 34(8): 537-554.

CARPENTER, M.A. \& SANDERS, W. 2002. Top management team compensation: The missing link between CEO pay and firm performance? Strategic Management Journal, 23(4):367-375.

CHARI, L. 2009. Measuring value enhancement through economic value added: Evidence from literature, IUP Journal of Applied Finance, 15(9):46-62. 
CHENG, S. \& INDJEJIKIAN, R. 2009. Managerial influence and CEO performance incentives. International Review of Law and Economics, 29:115-126.

COLLIER, D., IDENSOHN, K. \& ADKINS, J. 2010. Income inequality and executive remuneration: assessing the role of law and policy in the pursuit of inequality. South African Journal of Labour Relations, 34(2):84-109.

COUGHLAN, A.T. \& SCHMIDT, R.M. 1985. Executive compensation, management turnover, and firm performance: An empirical investigation. Journal of Accounting and Economics, 7(1):43-66.

DOSCHER, T. \& FRIEDL, G. 2011. Corporate governance, stakeholder power and executive compensation OR Spectrum, 33(2):309-331.

DUFFHUES, P. \& KABIR, R. 2008. Is the pay-performance relationship always positive? Evidence from the Netherlands. Journal of Multinational Financial Management, 18:45-60.

EDMANS, A. \& GABAIX, X. 2009. Is CEO pay really inefficient? A survey of new optimal contracting theories. European Financial Management, 15(3):486-496.

ELLIG, B.R. 2007. The complete guide to executive compensation. New York: McGraw-Hill.

ENGLUND, M. \& MACDONALD, R. 2008. Financial crisis slams retail, manufacturing, February 9, 2012. Available at: http://www.businessweek.com/investor/content/oct2008/pi20081015_679094.htm [accessed 2013-12-27].

ERIKSSON, T. \& LAUSTEN, M. 2000. Managerial pay and firm performance. Scandinavian Journal of Management, 16(3):269-286.

FAHLENBRACH, R. \& STULTZ, R.M. 2011. Bank CEO incentives and the credit crisis. Journal of Financial Economics, 99:11-26

FATEMI, A., DESAI, A.S. \& KATZ, J.P. 2003. Wealth creation and managerial pay: MVA and EVA as determinants of executive compensation. Global Finance Journal, 14(2):159-179.

FIRTH, M., FUNG, P.M. \& RUI, O.M. 2006. Corporate performance and CEO compensation in China. Journal of Corporate Finance, 12(4):693-714.

FRYDMAN, C. \& JENTER, D. 2010. Document Object Identifier (DOI): 10.3386/w16585. Published: Carola Frydman \& Dirk Jenter. "CEO Compensation." Annual review of financial economics. Annual Reviews, December, 2(1):75-102.

GABAIX, X. \& LANDIER, A. 2008. Why has CEO compensation increased so much? Quarterly Journal of Economics, 123(1):49-100.

GENTRY, R.J \& SHEN, W. 2010. The relationship between accounting market measures of firm financial performance: How strong is it? Journal of Managerial Issues, XXII(4):514-530.

GERHART, B. \& MILKOVICH, G.T. 1990. Organisational differences in managerial compensation and firm performance. Academy of Management Journal, 3(4):663-691.

GREGG, P., JEWELL, S. \& TONKS, I. 2005. Executive pay and performance in the UK 1994-2002. CMPO Working Paper Series, 05(122). Available at: http://people.exeter.ac.uk/ipt201/research/Executive Pay Performanceupdate6.pdf 05(122) [accessed 2014-09-02].

HALDANE, A.G. 2011. Bank of England. Available at: http://www.bankofengland.co.uk/publications/ speeches/2011/speech525.pdf [accessed 2012-02-05].

HAYNES, M., THOMPSON, S., \& WRIGHT, M. 2007. Executive remuneration and corporate divestment: Motivating managers to make unpalatable decisions. Journal of Business Finance \& Accounting, 34(5-6): 792-818

HOI, C.K. \& ROBIN, A. 2004. The design of incentive compensation for Directors. Corporate Governance, $4(3): 47-53$.

HOPE, O.K. \& THOMAS, W. B. 2008. Managerial empire building and firm disclosure. Journal of Accounting Research, 46(3):591-626.

INTERNATIONAL MONETARY FUND. 2009. Sound policies shield South Africa from worst recession. Available at: www.imf.org/external/pubs/ft/survey/so/2009/car092509a.htm [accessed 2009-09-2009].

JENSEN, M.C. \& MECKLING, W.H. 1976. Theory of the firm: Managerial behaviour, agency costs, and ownership structure. Journal of Financial Economics, 3(4):305-360.

JENSEN, M.C. \& MURPHY, K.J. 1990. Performance pay and top management incentives. Journal of Political Economy, 98(2):225-264. 
JENSEN, M. \& MURPHY, K. 1999. CEO incentives: It's not how much you pay, but how. Harvard Business Review, 3:64-76.

KING, M. 2009. King Report on Governance for South Africa. Institute of directors: Parktown.

KYRIAZIS, D. \& ANASTASSIS, C. 2007. The validity of the economic value added approach: An empirical application. European Financial Management, 13(1):71-100.

LEE, K.W., LEV, B. \& YEO, G.H. 2007. Executive pay dispersion, corporate governance, and firm performance. Review of Quantitative Finance and Accounting, 30(3):315-338.

LEON, P. 2012. Marikana, Mangaung and the South African mining industry (Webber Wentzel Report). Cape Town: Address to the South African Institute of International Affairs.

MADURA, J., MARTIN, A.D. \& JESSELL, K A. 1996. Determinants of CEO compensation in small publicity-traded business. American Business Review, 14(1):80.

MCKNIGHT, P.J. \& WEIR, C. 2009. Agency costs, corporate governance mechanisms and ownership structure in large UK publicly quoted companies: A panel data analysis. The Quarterly Review of Economics and Finance, 49(2):139-158.

MERHEBI, R., PATTENDEN, K., SWAN, P.L. \& ZHOU, X. 2006. Australian chief executive officer remuneration: Pay and performance. Accounting \& Finance, 46(3):481-497.

MODAU, M.F. 2013. The relationship between Chief Executive Officer (CEO) remuneration and financial performance of an organisation. Gordon Institute of Business Science (GIBS): Johannesburg.

MORRISSEY, J. 2009. More angry investors say, throw the boards out. Time Business and Money. Available at: http://www.time.com/time/business/article/0,8599,1925344,00.html [accessed 2009-09-23].

MURPHY, K. 1985. Corporate performance and managerial compensation: An emperical analysi. Journal of Accounting and Economics, 7:11-42.

NEL, M. 2012. Sensitivity of guaranteed cost to company of CEOs in the South African retail and consumer goods sector. Gordon Institute of Business Science (GIBS): Johannesburg.

O'REILLY, C.A. \& MAIN, B. G. 2010. Economic and psychological perspectives on CEO compensation: A review and synthesis. Industrial and Corporate Change, 19(3):675-712.

OZKAN, N. 2007. Do corporate governance mechanisms influence CEO compensation? An empirical investigation of UK companies. Journal of Multinational Financial Management, 17(5):349-364.

PETRA, S.T. \& DORATA, N.T. 2008. Corporate governance and chief executive officer compensation. Corporate Governance, 8(2):141-152.

RAJAN, R. 2005. Has financial development made the world riskier? National Bureau of Economic Research, Cambridge.

SCHOLTZ, H.E. \& SMIT, A. 2012. Executive remuneration and company performance for South African companies listed on the Alternative Exchange (AltX). Southern African Business Review, 16(1):22-38.

SHAW, P. 2011. CEO pay-performance sensitivity in South African financial services companies. Gordon Institute of Business Science (GIBS): Johannesburg

STATHOPOULUS, K., ESPENLAUB, S. \& WALKER, M. 2005. The compensation of the UK executive: Lots of carrots but are there any sticks. Competition and Change, 9(1):89-105.

STEWART, G. 1990. The quest for value. New York: Harper Collins.

SUNDAY TIMES. 2013. Bang goes bank boss pay. Sunday Times, 28 April:1.

TOSI J.R., H.L. \& GOMEZ-MEJIA, L.R. 1994. CEO compensation monitoring and firm performance. Academy of Management Journal, 37(4):1002-1016.

TOSI, H.L., WERNER, S., KATZ, J.P. \& GOMEZ-MEJIA, L.R. 2000. How much does performance matter? A meta-analysis of CEO pay studies. Journal of Management, 26(2):301-339.

VAN BLERCK, T.G. 2012. The relationship between executive remuneration at financial institutions and economic value added. Gordon Institute of Business Science (GIBS): Johannesburg

VELIYATH, R. \& BISHOP, J. 1995. Relationship between CEO compensation and firm performance empirical evidence of labour market norms. The International Journal of Organizational Analysis, 3(3): 268-283.

WARD, M. \& PRICE, A. 2006. Turning vision into value: corporate finance for non-financial executives. Pretoria: Van Schaik. 
WORLD AT WORK. 2011. Total reward framework. Available at: www.worldatwork.org [accessed 201106-25].

YANADORI, Y. \& MILKOVICH, G.T. 2002. Origin of CEO and compensation strategy: Differences between insiders and outsiders. Working Paper 44, Centre for Advanced Human Resource Studies. 